\title{
International Human Resource Management
}

\section{Astuti Mulang*}

Indonesia Timur University of Makassar, Indonesia

*Corresponding author: Astuti Mulang, Indonesia Timur University of Makassar, Indonesia, Tel: 0411421974; E-mail: eccetriana@yahoo.com

Rec date: Apr 28, 2017; Acc date: May 29, 2017; Pub date: June 05, 2017

Copyright: (C) 2017 Mulang A. This is an open-access article distributed under the terms of the Creative Commons Attribution License, which permits unrestricted use, distribution, and reproduction in any medium, provided the original author and source are credited.

\begin{abstract}
Global competition multinational companies can not only be faced with providing a reliable Human Resources. More than that the company should have a strategy and valuables sets, namely Human Resources who has committed, knowledgeable about the company in other countries, unable to compete face challenges and adapt quickly to new environments. Human Resources should be distributed and allocated in a way that can provide a competitive advantage. Management of Foreign Workers in this regard through expatriate assignments outside the country must be done by a company Manpower Indonesia, and with the right choice of strategy is an attempt to achieve corporate objectives.
\end{abstract}

Keywords: Strategies; Assignment; Expatriate

\section{Introduction}

Global competition faced by the nations of the world have implications in life. Both in the business world, political, social and cultural and ideological transformation. The various implications, could not be addressed by each country to accelerate and adapt on the global changes. For business organizations, global business will have a tendency on the activities of financial transactions, but has led to social interaction such as the establishment of international business alliances, cooperation between two or more multinational companies that are designed to benefit collectively.

Regarding the above description [1] said that Indonesia as the country with the fourth largest population in the world, Indonesia has provided a meaningful opportunity for foreign companies that traditionally rely on the expatriate her to mobilize and maintain operating companies the in Indonesia. The presence of expatriates in Indonesia is human capital (Human Capital) for the company. Attitude to do to prepare themselves for global competition that the business world includes: the intensification of the activity of research and development resources business organizations that are adaptive, reengineering on the pattern of applied management, prompted the government to deregulate and Debirokrasi rules and regulations for the sustainability of a healthy business climate, and expand your business or the company's operations to various countries. Having regard to the variety and complexity of the challenges facing the attitude that should be done, it will be much needed human resources superior quality and able to compete. The human resources are committed to the company and ready to compete face challenges is a treasure among other resources owned by the company, both tangible and intangible.

In addition, the management system is required Human Resources global prospective, meaning that management practices are applied must be flexible. Because it is not possible patterns applied management will go through various countries with different human objects. Human Resources of the company should be distributed and allocated in such a way in a way that can provide a competitive advantage and is a form of strategic management objectives. For the company's goals can be achieved, then the function of Human Resources should be integrated with the company's strategic management process, meaning that a Human Resources manager should:

- Have a strategic planning input, whether it be human issues related to business and disability in describing certain strategic alternatives.

- Have knowledge of the purpose of corporate strategy.

- Understand the types of skills, behaviour patterns and attitudes needed to support the strategic plan.

- Develop a program to ensure that employees or existing workers have the skills, behaviours and attitudes required by the company.

Associated with the above description, the subject matter that is discussed in the Human Resource Management Human Resource Management International is the possibility of employment outside the country who automatically have differences such as differences in culture, climate and values that become trust.

The scope of International Human Resource Management in general, [2] limits the scope of the International Human Resource Management includes the function, the type of workers and countries involved. The scope of the question is as follows:

\section{Human resource management functions include:}

- acquisition function, include: planning, withdrawal and socializing,

- function development, including: training, development and coaching,

- maintenance functions, including: health and safety and labour relations,

- motivational functions, including: evaluation, rewards, compensation and discipline.

\section{Type workers or employees may differ according to country} of origin, namely:

- Employees who come from countries where the company operates (local national) 
Page 2 of 5

- Employees from the company's home country (expatriates)

- Employees from third countries (third country national)

- While the countries involved in the operation, namely: a. Countries where the company operates (host country) b. The company's home country (home country), c. Other countries

- Schuler [2] divides the scope of the International Human Resource Management Home Host.

\section{Nationals local countries expatriates third country nationals type of employees}

Given the breadth of the operating area of International Human Resource Management, functions and activities performed in International Human Resource Management and a lot more wideranging than the domestic Human Resource Management. There are activities conducted International Human Resource Management but is not carried by the domestic Human Resource Management. These activities include adjustments to the rules and regulations or international law or the law of the country inhabited including the rules governing taxation, administration related to the expatriates, such as a passport/visa and other required documents, as well as the implementation of orientations for the expatriate.

These adjustments are applicable in any country in which the foreign worker will work. According to the Regulation of the Minister of Manpower and Transmigration [3] requirements that must be owned by foreign labour employed by the company in Indonesia is:

Have the education or work experience of at least five (5) years in accordance with the position that would be occupied.

Willing to make a statement to transfer the skills to Indonesian Manpower especially companion. What is meant by the Labour Companion (Candy, 2008) is a manpower Indonesia designated state and prepared as the companion of Foreign Workers.

Can communicate in Indonesian. In the case of positions that would be occupied by Foreign Workers. Already have work competency standards, then that will be employed must meet those standards.

- Indonesian Manpower assistants must have a background in the field of education in accordance with the position that would be occupied.

- Employers of foreign workers are required to report the use of foreign labour, and the companion of foreign workers in the company periodically every 6 (six) months to the director controlling use of foreign workers.

- Director controlling use of foreign workers, reported permit use of foreign workers issued periodically every 3 (three) months to the Minister with a copy to the director general.

- Besides those described above, International Human Resource Management also has a broader perspective than the domestic Human Resource Management, it is very possible because they must deal with a very heterogeneous group of employees.

Therefore, it is often in the practice of the International Human Resource Management allows for further participation in the life of the employee [4]. It is necessary in the activities of selection, training and effective management. Because the International Human Resource Management in practice is more influenced by external factors, such as the form of government, economy, and business practices host the International Human Resource Management has a very high risk of the failure of the implementation of the strategy. This failure was caused by the failure of workers who are stationed abroad, especially in the context of environmental and attitudinal adjustment is not successful [5].

\section{Definition of foreign workers}

Talking about the International Human Resource Management means we are talking about the workforce or employees who come from other countries, and matters relating to the preparation work in the destination country. Workers coming from other countries called the Foreign Workers for the country in which the foreign workers employed. Minister of manpower and transmigration [3] concerning procedures for utilization of foreign workers. What is meant by Expatriates are foreign nationals visa holder to work in Indonesia [6] defines that a person who left his home country to the other country to work, referred to as the Expatriate [4] categorizes people living outside their own country to work called Expatriate. While [7] in relation to Human Resource Management, in more detail to explain that: employees who work in an office or a company of which he is not a citizen of a country where the office or enterprise is located, but is a citizen of the country where the central office or the company is referred to as the Expatriate.

From the above it can be concluded that not all foreign labour can be referred to as expatriate, but an expatriate is a foreign worker. This paper is more focused towards foreign labour status as an Expatriate.

\section{Understanding of strategic management}

Before defining management strategy, it is necessary to define the word strategy. The word strategy comes from the ancient Greek that strategies. In military circles said the strategy is intended to win a battle. Mathis [7] defines strategy as the process of identifying the organization's goals and actions necessary to achieve that goal.

Strategic management is a process or an approach to dealing with competitive challenges and opportunities faced by the company, in other words the management strategy is the number of decisions and actions or efforts that led to the formulation of an effective strategy to help achieve the company's goals. Management strategy is basically a set shapes strategy, a process to analyse the competitive situation of companies in developing corporate strategy objectives and devise a plan of action and the allocation of resources that could improve the chances tangible achievement of organizational goals [6]. The choice of strategy is a response to substantial questions regarding the competition, which is how companies will compete to achieve the goals and mission. The decision in this selection is often associated with the underlying problem, for example, where it will compete, how to compete and in what manner will compete. In practice, the decision maker little or no attention to the problem "by what means will compete".

This decision has a broad impact on the company. Failure to anticipate problems above can lead companies do not know how they can compete, either in their own country where the parent company's operations and in other countries with which branch it operates. International Human

Resource management strategies is a link between the international Human Resource Management with strategic goals and objectives that are intended to improve business performance and develop corporate culture, to encourage and help to create, innovate more flexible. Strategic International Human Resource Management can also be 
interpreted as a pattern of human resource deployment planned and an act intended to assure and increase that the company can achieve its objectives.

In connection with the above description, the presence of the candidate expatriates Expatriate in this case, it must be properly managed by large companies that have international networks (MNCs $=$ Multinational Corporations) if the company it wants workers to succeed in their foreign assignments. Reviews These companies should be aware that high-performing employees in their own country can Easily Become a low-performing employee in other countries [2]. To Anticipate the possibility that the company must have a plan and what the right selection strategy used for corporate purposes and to equip workers in the work in other countries where the conditions are different situations and with the parent company or the company's home (home country).

Strategies in the application of International Human Resource Management is done through a variety of activities, namely:

\section{Planning in international human resource management}

According to [2] Human Resource planning in general were properly requires certain measures relating to the activities of Human Resource planners towards a competitive company. These steps are:

- Collection and analysis of data to forecast the demand and supply of human resources for the expected future business planners

- Develop Human Resources planning purposes

- Design and implement programs that can Facilitate the achievement of the company in Human Resources planning purposes

- Supervision and Evaluate programs that are running.

The fourth stage can be implemented for the achievement of shortterm goals $<1$ year, 2-3 years medium, and long term $>3$ years. As well as planning activities, Human Resources in general above, in International Human Resource planning is required an external labour market analysis from, whether they are local or domestic or international. This analysis is Necessary to Determine the needs or in the provision of labour associated with the skills and expertise required in international business. In the framework of this plan need to consider several aspects, Including:

- Determination as well as the identification of potential or criteria that must be met at each level of the management.

- Process of identifying crucial factors in bisnis International.

- Formulation of steps that must be done to Streng then the commitment to the development of an international career.

- Linking Human Resources planning by strengthening the skills required by the executive using strategic business planning.

- Expansion of opportunities for self- development workers.

- Distribution of units in the business held by focusing efforts on international business goal achievement.

\section{Recruitment and Selection}

Recruitment prospective employer/employee is the process undertaken by the company to find workers potential, while the selection of related to the process where companies seek to identify job seekers/applicants using the knowledge, skills, abilities and other features to help the company Achieve its goals. The strategy of the company will have an impact directly on the type of workers who were sought to be recruited and selected by the company. The process of recruitment and selection of candidates for expatriate done more rigorously selective Danlebih. Prospective workers required is truly ready for Reviews their cross-cultural challenge, has a highly competent and experienced in their field, have extensive knowledge about the major companies Similar in other countries, preferably from executive groups. The models that can be applied in the recruitment and selection by the companies that operate and on an international scale by $[8,9]$ Among others:

- Selected from the group of the national executive that is in the parent company (home country), to be placed in the company branch (host country) in other countries.

- Recruiting executives from countries where labour in the country or locally.

- Trying to adopt executives who have an international perspective without restricting citizenship.

From the survey on expatriate selection, $[5,10]$ reported that as many as 1,750 organizations representing 20 million employees and 175,000 professionals Human Resources policies using a selection of international assignments are as follows: pre-assignment using the visit as much as $60 \%$; their language training as much as $34 \%$; family readiness evaluation as much as 26\%; evaluation of cultural understanding as much as $15 \%$.

\section{Settings or management staff}

In the framework of the arrangement or management staff must consider a variety assumptions as following: at the same position, but in a different place then would require specific skills, cultural and physical environment influences locals must be carefully Considered and should be avoided estimates that wrong, besides than it according $[11,12]$ in the settings or managing staff should use a variety of criteria International, Among others:

- Prospective employees must have a personality that is patient, persevering, full of initiative and flexible accept or to experiment on new things in the job.

- Prospective employees should have high technical skills and appropriate technology with progress. In addition to technical skills, prospective employees must have the skills of communication also in the which includes mastery of the language.

- Prospective employees should have a high tolerance for differences of race, creed or religion, color, values, habits, and customs and traditions.

- Prospective employees must be highly motivated and defended.

- Prospective employees should have a good behaviour in the membership of a larger community.

\section{Orientation or Debriefing}

This activity is done to equip prospective employees who will go to other countries where he is assigned. Besides debriefing in their respective sectors, supply is also given with the aim to adapt, by studying the pattern of life and culture of the country that will be addressed. Here is intended as a characteristic cultural understanding in their behaviour or way of doing something wherewith formed by the surrounding environment within a long time. This In the case of companies should help employees who will be placed in the other state to be a part of world culture and have an identity as an expatriate. 
Enterprises become part of the culture of other countries is not intended as an effort to be like living in other countries, but also as an effort to improve the ability to understand strangers through reviews their attitudes and behaviour, including emphasis on language acquisition. Mastery of the language includes both mastery communicate orally and in writing and mastery of communication ethics. Mastery of communicating important ethics for ethics in communication between countries differ from one another with that. Unfamiliarity in the ethics of communication may cause failure or workers repatriated to the country of origin before the work is completed. Orientation activities carried out next, when it has arrived in the country of destination. Orientation is meant to do an introduction to the environment, introduction to the unit of work and workers, as well as the orientation of the work that became the main tasks of workers who concerned. The workers who can understand Reviews their culture, language and patterns of another state is considered as a worker a cosmopolitan item, namely workers who have high sensitivity to cultural differences, language and patterns of life and be able to accept and adjust to the peculiarities of foreign people's behaviour.

\section{Training and development}

Training is defined as a business that is planned with the learning providing facilities work associated with the knowledge, skills and behaviour of the workers/employees. While the development about the way to gain the skills and patterns of behaviour that can improve and increase of their ability so that work can overcome the challenges faced today or job come. In the future the company will change strategy often generally require changes in behaviour patterns, types, levels and skills mix through recruitment, selection, training and development workers/employees, so the company is able to describe the strategy of what is appropriately applied to change In practice, education and training program is a comprehensive coverage, starting from the interpersonal relationships, understanding of local culture or local, understanding the values and consumer behaviour through to operational global company, the transfer of the corporate culture, values in the culture of pluralistic, business systems, international strategy, socialization and other techniques. In the expatriate training and development process often tests also try to understand the culture of another country by way of sending it to other countries during a certain time (pre-assignment) to learn to adapt to new environments.

\section{Provision of compensation and rewards}

Compensation and rewards practice at the expatriate has a significant role in defining a strategy. The compensation is intended to attract and retain qualified workers in business between countries, facilitate movement between branches in different countries, the maintenance relationship that is consistent and keep the compensation provided is rational and supports efforts to excel in minimal competition with competitors terdekatnya. In the achievement the purpose, there are two principles in Determining remuneration system compensation or International company's items, namely:

- The concept of remuneration in accordance with the central company/the company's home (home country)

- The concept of remuneration with the remuneration referred modular. That approach with a modular approach is separated from the compensation package that regulations of the country of origin or adapted to the regulations in the countries where the firm operates (host country)
Compensation system is carried out depends on the rules and agreements with the company's home early in countries where the company operates.

\section{Conclusion}

Global competition in the business world for companies that have an international network of very influential on the need for quality human resources and the company's efforts in determining what the right strategy is used to deal with competitors. Human Resources (expatriate) quality is that committed, ready to compete face the challenge, have high competence in the field as well as fast-adapt. Companies large companies that assign workers to other countries where the company operates, should know that the workers/employees who perform well in the country can change be under-performing in other countries.

To address this the company must have a plan and choosing the right strategy. Strategies can be done through various activities items, namely: planning, recruitment and selection, settings and management staff, providing orientation or debriefing, training and development, and compensation and rewards. in the plan required prospective expatriate workforce needed for the external analysis determine the skills and labour requirements associated with membership.

Obtained needs through the recruitment and selection process, the which subsequently prepared given a briefing or orientation. Preassignment is an options strategy that is often done in the process of training and development. The provision of compensation and rewards to the expatriate aims to attract and retain qualified workers, ease of transfer between branches, the maintenance of the relationship between the parent company and branches and support for efforts to excel in competition. Compensation and rewards system depends on the rules and the initial agreement between the parent company and subsidiary companies.

\section{References}

1. Baert H, Govaerts N (2012) Learning patterns of teams at the workplace. J Workplace Learning 24: 538-550.

2. Savelsbergh C (2012) Team role stress: Relationships with team learning and performance in project teams. Dev Learning Org Int J 26: 67- 100.

3. Cross R, Gray P, Cunningham S, Showers M, Thomas R (2010) The collaborative organization: How to make employee networks really work. MIT Sloan Manag Rev Fall 52: 83-90.

4. Hendrickson J (2012) The capable utility company: Redefining performance for the new business environment, booz \& company.

5. Coghlan D, Rigg C (2012) Action learning as praxis in learning and changing. Res Org Change Dev 20: 59-89.

6. Garvin D (2000) Learning in Action: A guide to putting the learning organization to work. Harvard School Business Press, Boston, Massachusetts, USA.

7. Horwitz SK, Horwitz IB, Barshes N (2011) Addressing dysfunctional relations among health care teams: Improving team cooperation through applied organizational theories. Adv Health Care Manag 10:173-197.

8. Nahrgang J, DeRue DS, Hollenbeck JR, Spitzmuller M, Jundt D, et al. (2013) Goal setting in teams: The impact of learning and performance goals on process and performance. Organ Behav Hum Decis Process 122:12-21.

9. Edmondson A (1999) Psychological safety and learning behaviour in work teams. Admin Sci Q 2: 350.

10. Maurer I (2010) How to build trust in inter-organizational projects: The impact of project staffing and project rewards on the formation of trust, 
Citation: Mulang A (2017) International Human Resource Management. J Socialomics 6: 203. doi:10.1472/2167.0358.1000203

Page 5 of 5

knowledge acquisition and product innovation. Int J Proj Manag 28 629-637.

11. Edmondson A, Carroll J (2002) Leading organisational learning in health care. Qual Saf Health Care 11: 51-56.
12. Edmondson A (2012) Teaming: How organizations learn, innovate, and compete in the knowledge economy, Jossey-Bass Publishing, San Francisco, CA, USA. 